\title{
Fish and macrocrustacean use of submerged plant beds in tidal freshwater marsh creeks
}

\author{
Lawrence P. Rozas \& William E. Odum \\ Department of Environmental Sciences, Clark Hall, University of Virginia, Charlottesville, Virginia 22903, USA
}

\begin{abstract}
Fishes and macrocrustaceans (nekton) were sampled biweekly from mid-June through October 1985 from submerged aquatic vegetation (SAV) and during September 1985 from unvegetated areas of tidal freshwater marsh creeks. Nineteen species of fishes $(6918$ individuals, $3.068 \mathrm{~kg}$ preserved wet weight) from 9 families, and 3 species of invertebrates (12036 individuals, $1.577 \mathrm{~kg}$ preserved wet weight) were collected from SAV The most abundant species were grass shrimp Palaemonetes pugio, banded killifish Fundulus diaphanus, mummichogs $F$, heteroclitus, bluespotted sunfish Enneacanthus gloriosus, and mud crabs Rhithropanopeus harrisii. Recruitment of small juvenile fishes of several species coincided with the period of greatest SAV areal cover (late June through September). Average densities of fauna were significantly greater in SAV than over nearby unvegetated creek bottoms in September. Faunal abundance was not significantly related to SAV biomass, perhaps because the structural complexity of the SAV in our study area was high and nekton were abundant when SAV was present at low densities (i.e. low biomass). The numerically dominant species that occurred in SAV at low tide and on the marsh surface at high tide were similar Grass shrimp, banded killifish, mummichogs and bluespotted sunfish accounted for $>90 \%$ of the total number of organisms collected in each of the 2 habitats, SAV and marsh surface. The SAV of tidal freshwater marsh creeks is probably most important as habitat for forage fishes. Young of recreational species such as bluegill Lepomis macrochirus and pumpkinseed $L$. gibbosus also occupy this habitat.
\end{abstract}

\section{INTRODUCTION}

The macrofauna associated with seagrasses or other species of submerged aquatic vegetation (SAV) have been the subject of numerous studies in marine, estuarine and freshwater environments (Hall \& Werner 1977, Mittelbach 1981, Crowder \& Cooper 1982; reviews by Orth et al. 1984, Pollard 1984). A number of laboratory and field studies have shown that SAV functions as a refugium and foraging area for many associated fauna (Nelson 1979, Coen et al. 1981, Heck \& Thoman 1981, Crowder \& Cooper 1982, Savino \& Stein 1982, Werner et al. 1983, Gilinsky 1984, Watanabe 1984, Leber 1985). Because these aquatic habitats afford protection from predation and provide foraging sites, they are generally recognized as valuable nursery areas for juvenile fishes and decapods (Thayer et al. 1978).

Although studies of SAV are numerous, few of these have included upper estuarine environments until recently (Heck \& Thoman 1984). The decline in submerged vegetation throughout the Chesapeake Bay estuary in recent years (Orth \& Moore 1984, Davis
1985) has prompted studies of SAV in the upper Bay (Kemp et al. 1984), but these have overlooked the tidal freshwater region of the estuary. Consequently, we know little about the macrofauna associated with SAV in tidal freshwater environments (Odum et al. 1984).

In this paper we (1) describe the composition, relative abundance, and seasonal abundance of the nekton (fishes and decapod crustaceans) associated with SAV in the creeks of tidal freshwater marshes on the Chickahominy River, (2) compare nekton abundance between vegetated and unvegetated areas of the tidal creeks, and (3) discuss similarities between the numerically dominant species of SAV and those species most commonly collected on the surface of tidal freshwater marshes.

\section{STUDY AREA AND SAMPLE SITES}

We sampled submerged plant beds in headwater creeks at Parsons Island Marsh $\left(37^{\circ} 21^{\prime} \mathrm{N}, 76^{\circ} 53^{\prime} \mathrm{W}\right)$, a tidal freshwater marsh located on the Chickahominy River approximately $18 \mathrm{~km}$ west of Williamsburg, Virginia, USA (Rozas \& Odum 1987). The mean amplitude 
of spring tides at the study area was $0.70 \mathrm{~m}$ (U. S. Department of Commerce 1984).

Collections were confined to tidal creeks of Stream Order 2 because these contained the greatest abundance of SAV (Rozas \& Odum 1987). Areal cover of SAV in the study creeks was 75 to $90 \%$ during peak abundance in late July. Submerged aquatic vegetation within the study area was dominated by water nymph Najas minor, an introduced species (Merilainen 1968). Two native species, coontail Ceratophyllum demersum and southern naiad Najas guadalupensis were also present but much less abundant. Water depth of the study creeks at low tide ranged between 9 and $53 \mathrm{~cm}$ $(\overline{\mathrm{x}}=26 \mathrm{~cm})$.

\section{MATERIALS AND METHODS}

Before sampling each creek, we monitored water temperature $\left( \pm 0.5 \mathrm{C}^{\circ}\right)$ and salinity $( \pm 0.5 \%$ ) with a YSI Model $33 \mathrm{~S}-\mathrm{C}-\mathrm{T}$ meter. We sampled SAV and organisms during the day at low tide with a $0.76 \mathrm{~m}$ high $1 \mathrm{~m} \times 1 \mathrm{~m}$ throw trap constructed of thin aluminum sheeting attached to an aluminum frame (Kushlan 1981). We slowly approached each sample site by boat and tossed the throw trap from the bow when approximately $3 \mathrm{~m}$ away. Because the throw trap readily sank into the soft creek sediments, organisms could not escape by swimming under the sides of the trap.

Vegetation within the throw trap was removed after vigorous shaking to dislodge organisms, placed into sample bags, and transported to the laboratory in a cooler. Samples were washed in running water, dried to constant weight at $105^{\circ} \mathrm{C}(48 \mathrm{~h})$, and weighed $( \pm 0.1 \mathrm{~g})$. Because roots broke off during sampling, they were not included in the biomass measurements.

Organisms were collected after the vegetation was removed by sweeping the inside of the throw trap 5 times with a bar seine. The bar seine consisted of $3 \mathrm{~mm}$ mesh netting, $1 \mathrm{~m} \times 1 \mathrm{~m} \times 0.5 \mathrm{~m}$ deep, attached to a Ushaped steel bar (each side $=1 \mathrm{~m}, 5 \mathrm{~mm}$ diameter). The contents of the bar seine were transferred to a $2 \mathrm{~mm}$ mesh bag and preserved in $35 \%$ formalin. After $72 \mathrm{~h}$, samples were washed in running water for $24 \mathrm{~h}$; organisms were separated from plant parts and detritus and transferred to $70 \%$ ethanol. Nekton were identified to species, counted and measured to the nearest mm (i.e. standard length for fishes, tip of rostrum to end of telson for shrimp, and carapace width for crabs). We separated all organisms into juveniles and adults based on the adult size of each species listed in Hildebrand \& Schroeder (1928), Carlander (1969, 1977), Lee et al. (1980), and Williams (1984). All individuals of each species were weighed together to the nearest $0.1 \mathrm{~g}$.

To estimate the efficiency of clearing the throw trap with a bar seine we used fin-clipped banded killifish, mummichogs and bluespotted sunfish and grass shrimp with clipped uropods and telsons. Organisms were released into the throw trap immediately after it had been thrown into a patch of SAV and the procedure described above was followed to remove vegetation and organisms.

To avoid depleting the SAV and affecting the use of this habitat by fish and macrocrustaceans, we chose not to repeatedly sample the same creeks throughout the study period. Collections were made biweekly on spring tides from 2 randomly selected creeks ( 6 samples $\mathrm{creek}^{-1}$ ) from mid-June through October 1985; the study period encompassed most of the SAV growing season (May through October). We sampled a total of 11 creeks, none more than 3 times. Sampling began and ended approximately $1.5 \mathrm{~h}$ before and after slack low water, respectively. Therefore, the marsh was completely drained and nekton were confined to the tidal creeks during the sampling period.

During September and October 3 rather than 6 samples of SAV were taken from each creek and 3 were collected from unvegetated areas. Because the abundance of most nekton and the areal cover of SAV dramatically declined in October, only the September samples were used to make comparisons of faunal densities between SAV and the unvegetated areas of the creeks.

\section{STATISTICAL ANALYSES}

We used a 2-way analysis of variance (ANOVA) to test for differences in fish and macrocrustacean densities between vegetated und unvegetated creek bottoms (Hull \& Nie 1981). To determine whether the abundance of organisms in SAV was positively related to plant biomass, we used a distribution-free test for ordered alternatives based on the Friedman rank sums test (Hollander \& Wolf 1973). This analysis was chosen because it required no assumptions of normality or homoscedasticity in the data, and allowed us to test for a relationship between biomass and nekton abundance while controlling for the affects of seasonality on these variables. We used 10 collections from June through August in the analysis for fish. Because macrocrustaceans were rarely collected in June and July, we performed the analysis for this group with only 4 August samples.

\section{RESULTS}

Water temperatures ranged from $34.0^{\circ} \mathrm{C}$ (August) to $11.0^{\circ} \mathrm{C}$ (October). Salinities were in the lower 
oligohaline range from mid-July through mid-August when the highest salinity was recorded $(1.1 \%)$. Freshwater conditions existed at other times during the study.

We collected a total of 18954 organisms with a preserved wet weight of $4.645 \mathrm{~kg}$ from SAV during the study period. The total catch included 19 species of fishes $(6918$ individuals, $3.068 \mathrm{~kg}$ preserved wet weight) from 9 families and 3 species of invertebrates (12036 individuals, $1.577 \mathrm{~kg}$ preserved wet weight) (Table 1).

Five species (grass shrimp Palaemonetes pugio, banded killifish Fundulus diaphanus, mummichog $F$. heteroclitus, bluespotted sunfish Enneacanthus gloriosus, and mud crab Rhithropanopeus harrisii) accounted for $97.0 \%$ of the total catch (Fig. 1). Four of the numerically dominant species (grass shrimp, banded killifish, mummichog and bluespotted sunfish) composed a significant portion of the total biomass (Fig. 1). Bluecrabs Callinectes sapidus, pumpkinseeds Lepomis gibbosus and American eels Anguilla rostrata also contributed significantly to the total biomass, but accounted for $<1 \%$ of the total catch. Most fishes $(93 \%)$ and invertebrates $(74 \%)$ taken in SAV were juveniles (Table 1).

Five sweeps of the bar seine captured 93 to $100 \%$ of

Table 1. List of fishes and macrocrustaceans collected in submerged aquatic vegetation (SAV) during the study period. Total number, total biomass (preserved wet weight), and percent of the total that were juveniles are given for each species

\begin{tabular}{|c|c|c|c|}
\hline Family, common name, species & Total no. & Total biomass $(\mathrm{g})$ & Percent juveniles \\
\hline \multicolumn{4}{|l|}{ Fishes } \\
\hline \multicolumn{4}{|l|}{ Anguillidae } \\
\hline American eel Anguilla rostrata (Lesueur) & 70 & 109.7 & 100 \\
\hline \multicolumn{4}{|l|}{ Cyprinidae } \\
\hline Golden shiner Notemigonus crysoleucas (Mitchill) & 3 & 15.6 & 33 \\
\hline Bridle shiner Notropis bifrenatus (Cope) & 6 & 2.6 & 17 \\
\hline Spot-tail shiner Notropis hudsonius (Clinton) & 4 & 12.1 & 50 \\
\hline \multicolumn{4}{|l|}{ Ictaluridae } \\
\hline Yellow bullhead Ictalurus natalis (Lesueur) & 7 & 1.3 & 100 \\
\hline Brown bullhead Ictalurus nebulosus (Lesueur) & 139 & 72.6 & 100 \\
\hline Channel catfish Ictalurus punctatus (Rafinesque) & 1 & 0.1 & 100 \\
\hline Tadpole madtom Notorus gyrinus (Mitchill) & 22 & 11.2 & 59 \\
\hline \multicolumn{4}{|l|}{ Cyprinodontidae } \\
\hline Banded killifish Fundulus diaphanus (Lesueur) & 4145 & 1077.8 & 98 \\
\hline Mummichog Fundulus heteroclitus (Linnaeus) & 1364 & 899.3 & 83 \\
\hline \multicolumn{4}{|l|}{ Poeciliidae } \\
\hline Mosquitofish Gambusia affinis (Baird \& Girard) & 110 & 19.4 & 54 \\
\hline \multicolumn{4}{|l|}{ Atherinidae } \\
\hline Inland silverside Menidia beryllina (Cope) & 42 & 0.3 & 100 \\
\hline \multicolumn{4}{|l|}{ Centrarchidae } \\
\hline Bluespotted sunfish Enneacanthus gloriosus (Holbrook) & 873 & 522.0 & 97 \\
\hline Pumpkinseed Lepomis gibbosus (Linnaeus) & 29 & 194.4 & 100 \\
\hline Bluegill Lepomis macrochirus Rafinesque & 5 & 84.1 & 60 \\
\hline Largemouth bass Micropterus salmoides (Lacepede) & 1 & 0.3 & 100 \\
\hline \multicolumn{4}{|l|}{ Percidae } \\
\hline Tessellated darter Etheostoma olmstedi Storer & 36 & 35.1 & 28 \\
\hline Yellow perch Perca flavescens (Mitchill) & 1 & 4.5 & 100 \\
\hline \multicolumn{4}{|l|}{ Gobiidae } \\
\hline Naked goby Gobiosoma bosci (Lacepede) & 60 & 5.3 & 95 \\
\hline \multicolumn{4}{|l|}{ Macrocrustaceans } \\
\hline \multicolumn{4}{|l|}{ Palaemonidae } \\
\hline Grass shrimp Palaemonetes pugio Holthuis & 11699 & 1214.0 & 75 \\
\hline \multicolumn{4}{|l|}{ Portunidae } \\
\hline Blue crab Callinectes sapidus Rathbun & 38 & 326.2 & 97 \\
\hline \multicolumn{4}{|l|}{ Xanthidae } \\
\hline Mud crab Rhithropanopeus harrisii (Gould) & 299 & 36.5 & 16 \\
\hline
\end{tabular}



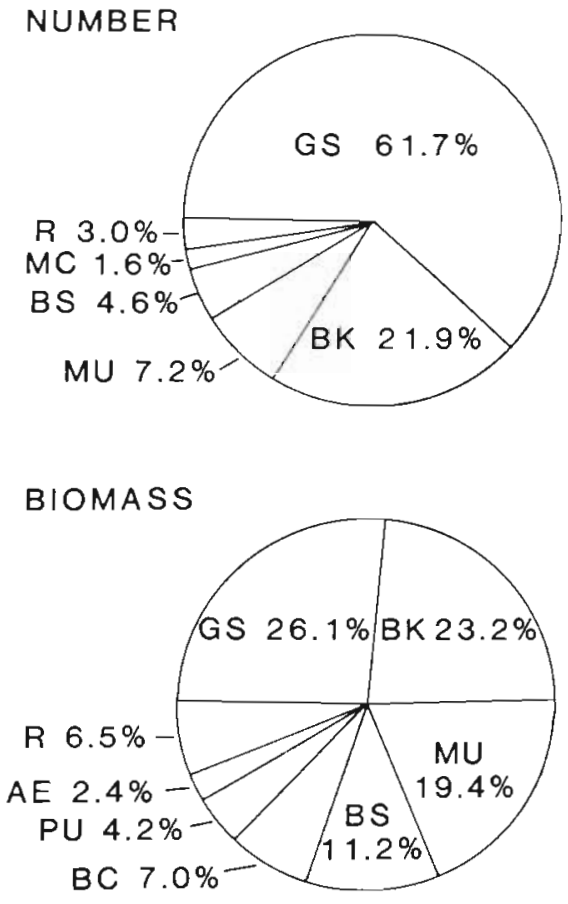

Fig. 1. Relative abundance (number of individuals) and relative contribution to total biomass ( $\mathrm{g}$ preserved wet weight) of the dominant species collected in submerged aquatic vegetation (SAV) during the study period. AE: American eel; BC: blue crab; BK: banded killifish; BS: bluespotted sunfish; GS: grass shrimp; $\mathrm{MC}$ : mud crab; $\mathrm{MU}$ : mummichog; PU: pumpkinseed $_{i} R_{\text {: remaining species }}$

Table 2. Efficiency estimates for the $1 \times 1 \mathrm{~m}$ bar seine used to clear the $1 \mathrm{~m}^{2}$ throw trap. Size range and mean (fish: standard length, shrimp: total length), number of tests (tests), number of organisms tested (total), and mean efficiency with $1 \mathrm{SD}$ (efficiency) are given for each species tested

\begin{tabular}{|lcccc|}
\hline \multicolumn{1}{|c}{ Species } & $\begin{array}{c}\text { Size range } \\
\text { (mean), mm }\end{array}$ & Tests & Total & Efficiency \\
\hline $\begin{array}{l}\text { Palaemonetes } \\
\text { pugio }\end{array}$ & $\begin{array}{c}26-42 \\
(32)\end{array}$ & 3 & 30 & $0.93 \pm 0.06$ \\
$\begin{array}{l}\text { Fundulus } \\
\text { diaphanus }\end{array}$ & $\begin{array}{c}22-40 \\
(29)\end{array}$ & 3 & 11 & $1.00 \pm 0.00$ \\
$\begin{array}{l}\text { Fundulus } \\
\text { heterocitus }\end{array}$ & $\begin{array}{c}29-52 \\
(39)\end{array}$ & 3 & 28 & $0.93 \pm 0.06$ \\
$\begin{array}{l}\text { Enneacanthus } \\
\text { gloniosus }\end{array}$ & $\begin{array}{c}20-54 \\
(30)\end{array}$ & 4 & 18 & $1.00 \pm 0.00$ \\
\cline { 1 - 5 } & & & \multicolumn{3}{c}{} \\
\hline
\end{tabular}

the 4 most numerous species (Table 2). The bar seine was most efficient for banded killifish and bluespotted sunfish but mummichogs and grass shrimp were also effectively collected.

Average standing crop of SAV was greatest in late July $\left(87.1 \mathrm{~g}\right.$ dry $\left.w \mathrm{~m}^{-2}\right)$, and declined to $12.3 \mathrm{~g}$ dry

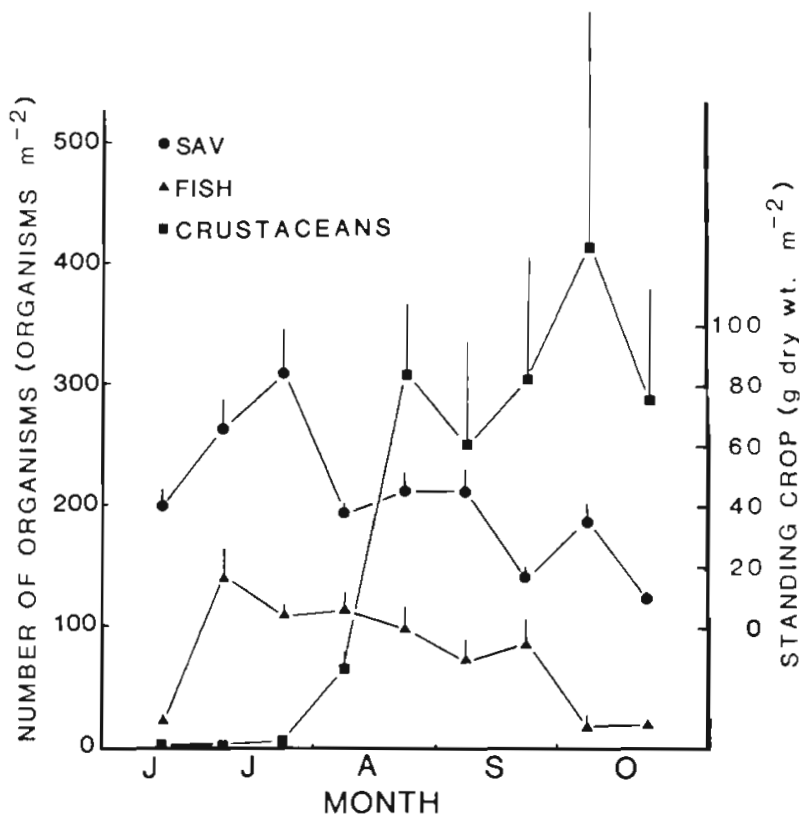

Fig. 2. Average number of fish (total fish $\mathrm{m}^{-2}$ ) and macrocrustaceans (total macrocrustaceans $\mathrm{m}^{-3}$ ) and average standing crop of SAV ( $\mathrm{g}$ dry $\mathrm{wt}^{-2}$ ) collected over the study period. Error bars represent $1 \mathrm{SE}$

wt $\mathrm{m}^{-2}$ in late October (Fig. 2). Although not significantly correlated with SAV biomass, fish densities in SAV followed a similar pattern; they peaked in July, gradually declined through September, and decreased dramatically after September (Fig. 2). Average macrocrustacean (mostly grass shrimp) densities increased steadily from late July through early October before declining in late October (Fig. 2).

Recruitment of the numerically dominant species to the SAV habitat exhibited a pattern of seasonal succession (Fig. 3). Brown bullheads Ictalurus nebulosus dominated the habitat in June, followed by banded killifish in July, and bluespotted sunfish in early September. Grass shrimp and mud crabs were not numerous until August, but unlike the fishes, they remained abundant into October.

Fish $\left(F_{1.16}=16.451, p \leq 0.001\right)$ and macrocrustaceans $\left(F_{1.16}=12.301, p \leq 0.003\right)$ were more numerous in submerged plant beds than over nearby unvegetated creek bottoms. The average density of fishes in September was almost 4 times greater in SAV than unvegetated areas and macrocrustaceans were an order of magnitude more abundant in SAV. Each of the 5 most abundant species in our study (grass shrimp, banded killifish, mummichogs, bluespotted sunfish and mud crabs) was much more abundant in SAV than unvegetated areas (Table 3 ). Neither the abundance of fishes ( $\mathrm{L}=757, \mathrm{p} \leq 0.19$ ) nor the number of macrocrustaceans $(\mathrm{L}=313, \mathrm{p} \leq 0.11)$ was significantly related to SAV biomass. 
Fig. 3. Average number of individuals (organisms $\mathrm{m}^{-2}$ ) of the 6 numerically dominant species collected over the study period. Error bars represent $1 \mathrm{SE}$
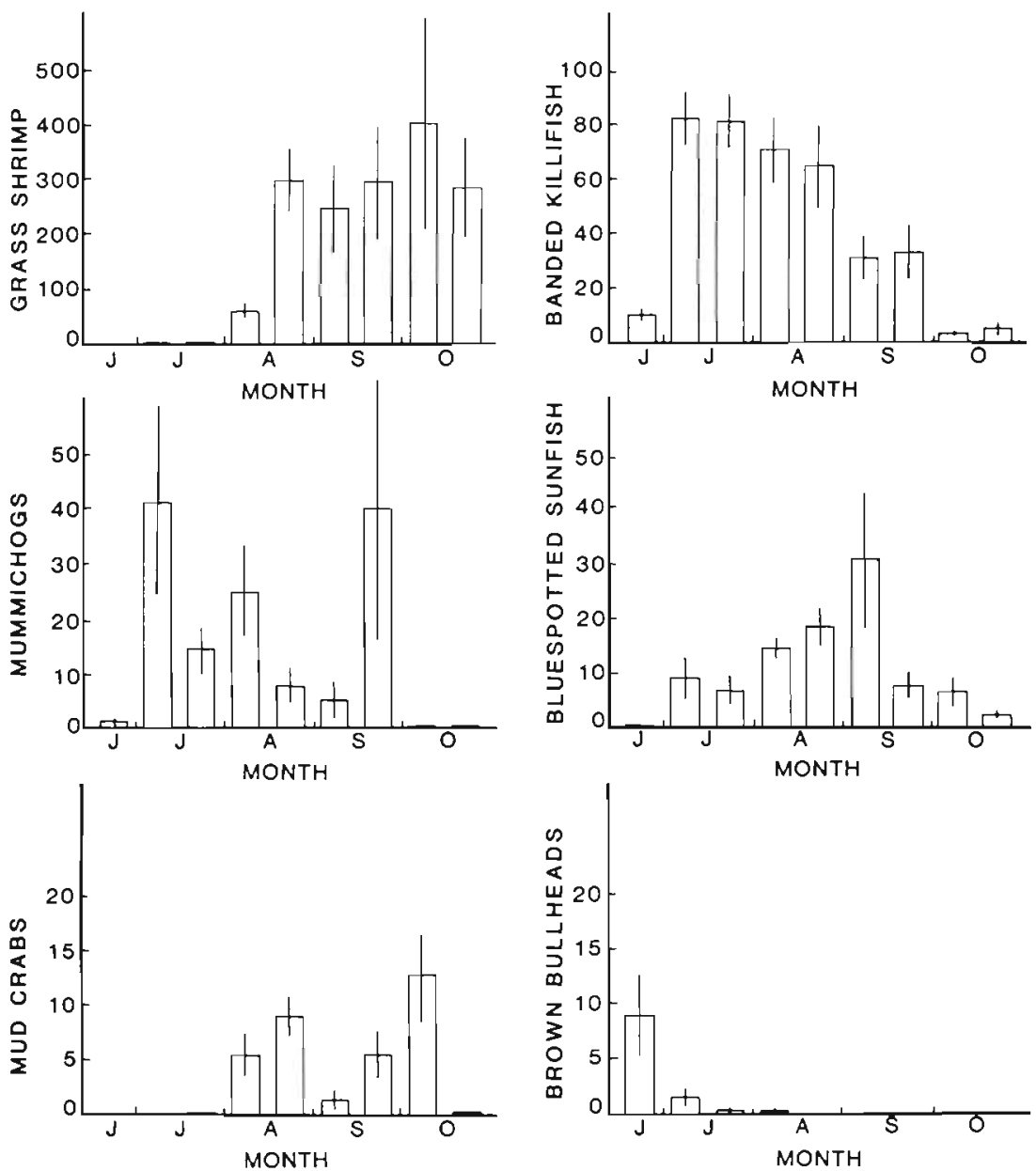

Table 3. Average number (ind $\mathrm{m}^{-2}$ ) $\pm 1 \mathrm{SE}$ of the 5 numerically dominant species collected during Sep 1985 in submerged aquatic vegetation (SAV) and nearby unvegetated areas of tidal creeks. Means computed from 12 samples of each habitat (SAV and unvegetated area); 3 samples from each of 4 creeks

\begin{tabular}{|lrr|}
\hline Species & \multicolumn{1}{c}{ SAV } & Unvegetated \\
\hline Palaemonetes pugio & $271 \pm 63.6$ & $36 \pm 17.6$ \\
Fundulus diaphanus & $31 \pm 6.1$ & $12 \pm 3.6$ \\
Fundulus heteroclitus & $23 \pm 12.5$ & $5 \pm 3.0$ \\
Enneacanthus gloriosus & $19 \pm 6.9$ & $1 \pm 0.4$ \\
Rhithropanopeus harrisii & $4 \pm 1.3$ & $0 \pm 0.0$ \\
\hline
\end{tabular}

\section{DISCUSSION}

Use of the $1 \mathrm{~m}^{2}$ throw trap was an effective means of quantitatively sampling most fish and macrocrustaceans in the SAV of tidal freshwater creeks. The vast majority of organisms collected were either juveniles or small species which are efficiently collected with the throw trap (Kushlan 1981). However, mummichogs were probably under-represented in our samples; on several occasions they avoided capture by swimming away from the boat as we approached the sample sites.

Five sweeps of the bar seine collected most organisms within the throw trap (Table 2). Use of the bar seine to clear the throw trap required less time (about $5 \mathrm{~min}$ ) than that reported when using either rotenone and dip nets (Wegener et al. 1973, Weinstein \& Brooks 1983) or a smaller clearing net (Freeman et al. 1984). Yet, the efficiency of the bar seine for the 4 most numerous species was greater than the $90 \%$ efficiency reported by Freeman et al. (1984).

The submerged plant beds of our tidal freshwater creeks were heavily used by several species of fishes and macrocrustaceans at low tide (Table 1). Average densities of fishes in our study were twice those found in Potamogeton perfoliatus beds of upper Chesapeake Bay (Kemp et al. 1984). Similarly, Heck \& Thoman (1984) found that densities of decapods and fishes excluding spot were much greater in vegetated habitats than nearby unvegetated sites of Chesapeake Bay. Kemp et al. (1984) found densities of fish 1 to 10 times greater in vegetated than unvegetated areas. Numerous studies of SAV in freshwater lakes (Hall \& 
Werner 1977, Werner et al. 1977, Mittelbach 1981) and seagrass beds (see review by Orth et al. 1984) have also reported high concentrations of fishes and macrocrustaceans in vegetated habitats

Unlike studies of seagrass beds (Heck \& Wetstone 1977, Heck \& Orth 1980, Stoner 1983), we did not find that faunal abundance was significantly related to plant biomass. Heck \& Thoman (1984) found no significant correlation between fish abundance and plant biomass in a Ruppia bed but decapod abundance was correlated with Ruppia biomass. Structural complexity may be the most important factor influencing the use of SAV (Heck \& Orth 1980, Coen et al. 1981). Compared to most seagrasses, the dominant species of SAV in tidal freshwater environments (i.e. water nymph and coontail) are structurally very complex and even at low densities (i.e. low biomass) may impart enough physical structure to creek bottoms to attract large numbers of fauna. Our finding of no significant relation between SAV biomass and faunal abundance may be due to organisms concentrating in SAV of low density as readily as denser vegetation.

During low tide, when the small fishes and macrocrustaceans of tidal freshwater marshes are concentrated in the tidal creeks, they are most susceptible to predation (Mclvor et al. unpubl.). Recent laboratory and field studies of estuarine (Nelson 1979, Coen et al. 1981. Heck \& Thoman 1981) and freshwater (Hall \& Werner 1977, Crowder \& Cooper 1982, Savino \& Stein 1982) habitats have shown that SAV provides protection to small fishes and invertebrates by reducing the foraging efficiency of large predators. Similarly, SAV likely provides an important subtidal refuge for the juveniles and small species that occupy tidal freshwater marsh creeks.

In addition to providing refugia for fishes and macrocrustaceans, SAV may support greater standing crops of invertebrate fauna per unit area than unvegetated tidal creek habitats (Gerking 1962, Menzie 1980 , Gilinsky 1984). Small invertebrates may be an important food source for some of the fishes that use SAV (Menzie 1980, Crowder \& Cooper 1982). Menzie (1980) found that the fish food potential of small invertebrates was increased substantially by the presence of SAV in the lower Hudson River. Although $<2 \%$ of the total area of the region was vegetated, Menzie (1980) estimated that SAV produced 14 to $25 \%$ of the total chironomid standing crop. Numerous amphipods, chironomids, and other insect larvae were observed on the stems and leaves of SAV during sample processing (pers. obs.).

Changes in the areal cover of SAV within the study creeks followed a pattern similar to that of the average standing crop of SAV (Fig. 2). Areal cover peaked in July and decreased through September and October; by the end of October SAV had all but disappeared from the tidal creeks in the study area (pers. obs.). The recruitment of small juveniles of several species of fishes to the study area coincided with the period (June through September) of greatest SAV areal cover (Fig. 2). Kemp et al. (1984) also found maximum abundance of fishes in SAV during this period of peak plant biomass.

Since our study was limited to one marsh complex and a 4 mo period within a single year, we know little about spatial and long-term temporal variations in the use of SAV habitats. However, we are certain that these occur. For example, juvenile pumpkinseeds and bluegills Lepomis macrochirus were much more abundant in marsh surface collections during 1984 than 1985 from a marsh on Morris Creek, $3.5 \mathrm{~km}$ southwest of our study site (McIvor 1987). Throw trap samples of SAV in Morris Creek in 1984 contained juvenile bluegill and pumpkinseed densities as high as 42 and 13 ind $\mathrm{m}^{-2}$, respectively (Rozas, unpublished data). Yet, these 2 centrarchids were uncommon in $1985 \mathrm{SAV}$ collections. Juvenile centrarchids are known to concentrate in the vegetated littoral zone of lakes (Werner \& Hall 1977) and likewise reside in the SAV of tidal freshwater marshes. Little recruitment of juvenile bluegills and pumpkinseeds to SAV occurred in 1985. but these 2 species are probably more abundant in SAV at other sites or may be more numerous at Parsons Island in other years than was documented in our study.

Many of the same species that resided in the SAV of tidal creeks at low tide occupied the flooded marsh surface at high tide (Rozas \& Odum 1987). Grass shrimp, banded killifish, mummichogs and bluespotted sunfish composed $95.4 \%$ of the total number of organisms collected in SAV; they accounted for $92.2 \%$ of the organisms taken on the marsh surface in concurrent sampling (Rozas \& Odum 1987). However, exceptions to this general overlap of species between the 2 habitats were apparent. The inland silverside Menidia beryllina was the third most numerous fish in samples of the marsh surface, but it was rarely collected in SAV. Other species that appeared to be more abundant on the marsh surface than in SAV were spot-tail shiners Notropis hudsonius, tessellated darters Etheostoma olmstedi, naked gobies Gobiosoma bosci, bay anchovies Anchoa mitchilli, and mummichogs. All of these species with the exception of the mummichog likely use the unvegetated areas of tidal creeks more than either of the vegetated habitats, marsh surface and SAV (McIvor et al. unpubl.). Species that seemed to show the greatest affinity for SAV were bluespotted sunfish, brown bullheads, tadpole madtoms Notorus gyrinus, American eels, banded killifish and mud crabs. 
We conclude that the SAV of tidal freshwater marsh creeks is not used as a nursery area by commercial species but is used by some recreational species (i.e. bluegills, pumpkinseeds). Instead, these areas are probably most important as habitat for forage fishes that are prey for species such as largemouth bass $\mathrm{MiC}$ ropterus salmoides, yellow perch Perca flavescens and white perch Morone americana. The availability of an abundant supply of these forage fishes may be essential in the recruitment of the juveniles of some species (i.e. largemouth bass) to the adult stock (Aggus \& Elliott 1975, Gutreuter \& Anderson 1985).

Acknowledgements. This work is a result of research supported in part by a Department Research Grant and Moore Award from the Department of Environmental Sciences, University of Virginia, and a grant (No. NA81AA-D-00025) to the Virginia Graduate Marine Science Consortium and the Virginia Sea Grant Program by the Office of Sea Grant, U. S. Department of Commerce. The authors thank D. Gauthier, C. McIvor, D. Mclvor and N. Tayal for field assistance. We thank K. Heck, C. McIvor and 4 anonymous reviewers for helpful comments on the manuscript; J. Porter and E. Connor for assistance with statistical analyses; R. E. Jenkins for assistance with fish identification and verification. C. Bowman is acknowledged for granting us permission to work on his property. We gratefully acknowledge the hospitality and logistical support provided by David Brime of the Virginia Commission of Game and Inland Fisheries.

\section{LITERATURE CITED}

Aggus, L. R., Elliott, G. V (1975). Effects of cover and food on year-class strength of largemouth bass. In: Stroud, R. H., Clepper, $H$. (ed.) Black bass biology and management. Sport Fishing Institute, Washington, D.C., p. 317-322

Carlander, K. D. (1969). Handbook of freshwater fishery biology, Vol. 1. Iowa State Univ. Press, Ames

Carlander, K. D. (1977). Handbook of freshwater fishery biology, Vol. 2. Iowa State Univ. Press, Ames

Coen, L. D., Heck, K. L., Jr., Abele, L. G. (1981). Experiments on competition and predation among shrimps of seagrass meadows. Ecology 62: 1484-1493

Crowder, L. B., Cooper, W. E. (1982). Habitat structural complexity and the interaction between bluegills and their prey. Ecology 63: 1802-1813

Davis, F. W. (1985). Historical changes in submerged macrophyte communities of upper Chesapeake Bay. Ecology 66: 981-993

Freeman, B. J., Greening, H. S., Oliver, J. D. (1984). Comparison of three methods for sampling fishes and macroinvertebrates in a vegetated freshwater wetland. J. Freshwater Ecol. 2: 603-609

Gerking, S. D. (1962). Production and food utilization in a population of bluegill sunfish. Ecol. Monogr. 32: 31-78

Gilinsky, E. (1984). The role of fish predation and spatial heterogeneity in determining benthic community structure. Ecology 65: 455-468

Gutreuter, S. J., Anderson, R. O. (1985). Importance of body size to the recruitment process in largemouth bass populations. Trans. Am. Fish Soc. 114: 317-327
Hall, D. J., Werner, E. E. (1977). Seasonal distribution and abundance of fishes in the littoral zone of a Michigan Lake. Trans. Am. Fish Soc. 106: 545-555

Heck, K. L., Jr., Wetstone, G. S. (1977). Habitat complexity and invertebrate species richness and abundance in tropical seagrass meadows. J. Biogeogr 4: 135-142

Heck, K. L., Jr., Orth, R. J. (1980). Seagrass habitats: the role of habitat complexity, competition and predation in structuring associated fish and macroinvertebrate assemblages. In: Kennedy, V. S. (ed.) Estuarine perspectives. Academic Press, New York, p. 449-464

Heck, K. L., Jr., Thoman, T. A. (1981). Experiments on predator-prey interactions in vegetated aquatic habitats. J. exp. mar. Biol. Ecol. 53: 125-134

Heck, K. L., Jr., Thoman, T. A. (1984). The nursery role of seagrass meadows in the upper and lower reaches of the Chesapeake Bay. Estuaries 7: 70-92

Hildebrand, S. F., Shroeder, W. C. (1928). Fishes of Chesapeake Bay. Fish. Bull. U.S. 18: 1-366

Hollander, M., Wolfe, D. A. (1973). Nonparametric statistical methods. John Wiley and Sons, New York

Hull, C. H., Nie, N. H. (1981). SPSS update 7-9. McGraw-Hill, New York

Kemp, W. M., Boynton, W. R., Twilley, R. R. (1984). Influences of submersed vascular plants on ecological processes in upper Chesapeake Bay. In: Kennedy, V. S. (ed.) The estuary as a filter. Academic Press, Orlando, p. 367-394

Kushlan, J. A. (1981). Sampling characteristics of enclosure fish traps. Trans. Am. Fish Soc. 110: 557-562

Leber, K. M. (1985). The influence of predatory decapods, refuge and microhabitat selection on seagrass communities. Ecology 66: 1951-1964

Lee, D. S., Gilbert, C. R., Hocutt, C. H., Jenkins, R. E., McAllister, D. E., Stauffer, J. R., Jr. (1980). Atlas of North American freshwater fishes. North Carolina State Museum of Natural History, Raleigh

McIvor, C. C. (1987). Marsh fish community structure: roles of stream geomorphology and salinity. Ph. D. dissertation, Univ. of Virginia, Charlottesville

Menzie, C. A. (1980). The chironomid (Insecta: Diptera) and other fauna of a Myriophyllum spicatum L. plant bed in the lower Hudson River. Estuaries 3: 38-54

Merilainen, J. (1968). Najas minor All. in North America. Rhodora 70: 161-175

Mittelbach, G. G. (1981). Foraging efficiency and body size: a study of optimal diet and habitat use by bluegills. Ecology 62: $1370-1386$

Nelson, W. G. (1979). Experimental studies of selective predation on amphipods: consequences for amphipod distribution and abundance. J. exp. mar. Biol. Ecol. 38: 225-245

Odum, W. E., Smith, T. J., III, Hoover, J. K., Mclvor, C. C. (1984). The ecology of tidal freshwater marshes of the United States east coast: A community profile. U.S. Fish Wildl. Serv., FWS/OBS-83/17

Orth, R. J., Moore, K. A. (1984). Distribution and abundance of submerged aquatic vegetation in Chesapeake Bay: an historical perspective. Estuaries 7: 531-540

Orth, R. J., Heck, K. L., Jr., van Montfrans, J. (1984). Faunal communities in seagrass beds: a review of the influence of plant structure and prey characteristics on predator-prey relationships. Estuaries 7: 339-350

Pollard, D. A. (1984). A review of ecological studies on seagrass-fish communities, with particular reference to recent studies in Australia. Aquat. Bot. 18: 3-42

Rozas, L. P., Odum, W. E. (1987). Use of tidal freshwater marshes by fishes and macrofaunal crustaceans along a marsh stream-order gradient. Estuaries 10 (1): in press 
Savino, J. F., Stein, R. A. (1982). Predator-prey interaction between largemouth bass and bluegills as influenced by simulated, submersed vegetation. Trans. Am. Fish. Soc 111: $255-266$

Stoner, A. W. (1983). Distribution of fishes in seagrass meadows: role of macrophyte biomass and species composition. Fish. Bull. U.S. 81 : 837-846

Thayer, G. W., Stuart, H. H., Kenworthy, W. J., Ustach, J. F. Hall, A. B. (1978). Habitat values of salt marshes, mangroves, and seagrasses for aquatic organisms. In: Greeson, P. E., Clark, J. R., Clark, J. E. (ed.) Wetland functions and values: the state of our understanding. American Water Resources Associaton, Minneapolis, p. 235-247

U.S. Department of Conmerce (1984). Tide Tables 1985 (High and Low Water Predictions) East Coast of North and South America, Including Greenland. NOAA National Ocean Survey, Rockville, Maryland

Watanabe, J. M. (1984). The influence of recruitment, competition and benthic predation on spatial distributions of three species of kelp forest gastropods (Trochıdae: Tegula). Ecology 65: 920-936

Wegener, W., Holcomb, D., Williams, V (1973). Sampling shallow water fish populations using the Wegener ring. Proc. S. E. Ass. Game Fish Comm. 27: 663-674

Weinstein, M. P., Brooks, H. A. (1983). Comparative ecology of nekton residing in a tidal creek and adjacent seagrass meadow: community composition and structure. Mar. Ecol. Prog. Ser. 12: 15-27

Wemer, E. E., Hall, D. J., Laughlin, D. R., Wagner, D. J., Wilsmann, L. A., Funk, F. C. (1977). Habitat partitioning in a freshwater fish community. J. Fish. Res. Bd Can. 34: 360-370

Werner, E. E., Gilliam, J. F., Hall, D. J., Mittelbach, G. G. (1983). An experimental test of the effects of predation risk on habitat use in fish. Ecology 64: 1540-1548

Williams, A. B. (1984). Shrimps, lobsters, and crabs of the Atlantic coast of the eastern United States, Maine to Florida. Smithsonian Institution Press, Washington, D.C.

This article was presented by Dr G. W. Thayer; it was accepted for printing on February 26, 1987 